\title{
THE INFLUENCE OF THE 'TOMOS NARRATIVE' AS A PART OF THE UKRAINIAN NATIONAL AND STRATEGIC NARRATIVE
}

\author{
ARTEM ZAKHARCHENKO - OLENA ZAKHARCHENKO ${ }^{l}$
}

\begin{abstract}
One of the most prominent parts of the 2019 Ukrainian presidential election was the mediatized topic of achieving Ukrainian church independence, and its symbol, the tomos document received from the Ecumenical Patriarch in January 2019. This process was a part of incumbent president Petro Poroshenko's electoral campaign. Narrative analysis of this topic showed that it had a structure similar to that of classic Hollywood plots. It is unlike most other media narratives present in the information space. We prove that this topic had a major influence on its audience: media attention to the topic of Tomos was found to be closely correlated to Google search data associated with the 'tomos' search term and with electoral support for Poroshenko. However, this narrative's audience was limited to the patriotic electorate, thus Poroshenko did not win the election. Nevertheless, the Tomos story became so influential that it can be considered a part of national and strategic narratives.
\end{abstract}

KEYWORDS: media narrative, strategic narrative, narrative analysis, electoral campaigns, narrative involvement, media influence, Tomos

1 Artem Zakharchenko, Ph.D. in social communications, docent in Multimedia Technologies and Media Design Department, Institute of Journalism, Taras Shevchenko National University of Kyiv; research director in the Center for Content Analysis; has 17 years of working experience as a journalist and editor in leading Ukrainian media, email: artem.zakh@gmail.com. Olena Zakharchenko works as analyst in the Center for Content Analysis, in Kyiv, besides she is a fiction writer, email: olena.amoli@gmail.com. This paper was funded by Fulbright program of the Institute of International Education and the Center for the Content Analysis, Kyiv, Ukraine. 


\section{INTRODUCTION}

\section{Media, electoral, national, and strategic narratives}

The concept of the narrative is now widely used in the humanities. Scientists particularly emphasize its identity-shaping power. This power is common to different narrative types, such as media narratives, social media narratives, political narratives, electoral narratives, religious narratives, national narratives, and strategic narratives.

All these kinds of narratives are deeply intersecting and may be distinguished only for specific research purposes. They are all dimensions of Lyotard's 'grand narrative' (Lyotard et al. 1984), and could be classified using the criteria of Ochs and Capps' (Ochs-Capps 2001) as nonlinear stories with plural narrators with flexible moral positions, a high level of 'tellability,' and strong embedding in the current context.

Particularly after the emergence of the internet, media narratives became a continuous, non-discrete information flow with a transmedia structure (Herman 2004). This is usually described in terms of 'collapsed context,' which means that nobody can predict the background nor therefore the reaction of recipients who may see it (Musolff 2005). Media narratives consist of many topics of varying duration, integrated similarly to plot lines in TV series (Zakharchenko 2017). Most of these narratives have a chaotic structure and may not be described as good stories: they include sudden breakdowns, and overly long gaps in plot development, etc.

The social media narrative is usually constituted as either a 'breaking news' structure that is open-ended and branching, even in the case of private conversations, or as a so-called 'living narrative' - i.e. involving the tales of average people sat around the fireplace (Ochs-Capps 2001:12).

Among the most powerful narratives are religious ones. For example, the fragments of the biblical narrative are repeated a million times in different contexts and situations as metaphors for everyday life (Pihlaja 2017).

The national narrative is also composed of media or social media texts, as well as of private real-life conversations, official speeches, textbooks, and the whole educational process, literature, and other artistic content. K.V. Korostelina found (Korostelina 2014) that the typical national narrative has three levels: dualistic order (describing in-group and out-group), mythological narratives, and a normative order (explaining the political order typical of a nation). Each of these levels is used for shaping identity and legitimizing power.

The concept of the strategic narrative is very similar to the national one, but it is usually applicable to the area of warfare. Both narrative types unite people 
on the emotional level and therefore help to govern military action; a strategic narrative is usually designed especially for this purpose (Pocheptsov 2012). The United States Department of Defense has a similar view of this term: "A key component of the narrative is establishing the reasons for and desired outcomes of the conflict, in terms understandable to relevant publics" (JDN 2013).

Electoral campaigning narratives are described in several papers - for example, in the story of anti-politician superhero D. Trump in the 2016 US electoral campaign (Schneiker 2019), a many-voiced narrative of the 2008 Obama campaign (Capone 2010), the Musharraf campaign in Pakistan in 2008 (Burnes 2011), and even the story of Theodore Roosevelt's tattoos during the time of the presidential election of 1912 (Hoenig 2020).

\section{Narrative involvement}

All these narratives are useless if they cannot involve recipients in reading and participating in their creation. Busselle and Bilandzic identify four phases of narrative involvement: understanding, attention focus, emotional engagement, and narrative presence (Busselle-Bilandzic 2008).

The latter authors distinguish three types of mistrust in narratives: perceived fictionality (the least important aspect), inconsistency with external circumstances, and the absence of internal logic. Researchers conclude that only the second and third types lead to a lack of involvement. Accordingly, the persuasive ability of a narrative is determined by its narrative structure and conformity with dominant stereotypes rather than by its factuality (BusselleBilandzic 2008:266-267).

Sometimes narrative involvement is so powerful that people 'dissolve' in the narrative and start to perceive it as a part of real life and to identify with the characters. This may happen with a book, film, or video game. The most comprehensive form of involvement leads recipients to act in line with the logic of the narrative. There are three eloquent examples of such involvement.

The first one is game-related engagement. The best example of this is 'Pokemon Go' - the augmented reality game by Nintendo. Nedelcheva notes that this involves a new generation of transmedia storytelling "that takes computer games to the streets and ultimately, beyond" (Nedelcheva 2016:3749). Embedded in contemporary lifestyles, it builds "human-to-human and human-to-technology relationships in the over connected world" (Nedelcheva 2016:3750).

The second example is involvement in the protest narrative mediated by social networks. Gerbaudo called this phenomena 'digital enthusiasm.' It appears as a result of positive emotional interactions between members and administrators of 
protest communities, or opinion leaders, leading to a self-reinforcing emotional cycle: "Thus the content of user comments reinforced from the bottom-up the top-down narrative proposed by the admins and strongly contributed to creating a favorable climate of hope and reciprocal trust - the kind known to be propitious for facilitating protest participation" (Gerbaudo 2016:268).

The third example is the involvement of social media users in the "spectacle of the 2016 U.S. presidential election" (Mihailidis-Viotty 2017).

\section{Ukrainian elections 2019 as the identity-shaping driver}

The relationship between narrative involvement and people's identity is strongest in times of huge social upheavals like disasters, revolutions, or elections (Seeger-Sellnow 2016).

Agenda-setting theory postulates that social issues that are more salient in the media are usually perceived as more important by their audience (McCombsShaw 1972). As a result, parties or candidates who 'own' those issues have higher electoral ratings (Sides 2006).

In the recent Ukrainian elections, there was a varied selection of differing agendas. The incumbent Petro Poroshenko, leader of the party European Solidarity, who became president based on the wave of patriotism that occurred after the Revolution of Dignity but was later repeatedly accused of corruption, owned the patriotic agenda. The social agenda was promoted by some candidates, the most popular of whom was Yuliia Tymoshenko, leader of the 'Batkivshchyna' ('Motherland') party, an ex-prime minister who usually used patriotic rhetoric but was accused of being affiliated with agents of Russian influence. The other group of candidates maintained the anti-corruption agenda; this group was led by led by Anatolii Hrytsenko, ex-Minister of Defence (Zakharchenko et al. 2019). But the leader of the elections became Volodymyr Zelenskii, a former comedian without any political experience, supported at the time by oligarch Igor Kolomoyskii and his TV channel ' $1+1$,' on which Zelenskii's TV show was broadcast. A unique feature of Zelenskii's campaign was the phenomena of 'non-agenda owning' - meaning that he avoided making any specific statements about political and economic issues, so he enjoyed the support of people with contrasting expectations (Zakharchenko 2019).

In the frame of narratives, there were two big stories told by candidates. The first one involved the 'Servant of the people' TV series that described the life of a school teacher, Vasyl Holoborodko, who surprisingly won the presidential elections and started changing Ukraine. Zelenskii's main role in this series shaped his perception by the electorate. The second was the narrative of Tomos: 
the story of the process of the acquisition of independence by the Orthodox Church of Ukraine (OCU), with the direct participation of Petro Poroshenko. This church was created of two unadmitted churches: the Ukrainian Orthodox Church - Kyiv Patriarchate (UOC KP), and the Ukrainian Autocephalous Orthodox Church (UAOC), and some of the parishes from the Ukrainian Orthodox Church - Moscow Patriarchate (UOC MP), which is subordinated to the Russian Orthodox Church (ROC). This long story unveiled its plot gradually in the media and finished with the receipt of the tomos - the document which certified the church's independence.

The fact is that the story of receiving the tomos for the Ukrainian church lasted much longer than the presidential campaign of 2019. The Ukrainian church came under Russian power in 1686. Since then, the Ukrainian priesthood has tried several times to achieve independence during the periods of national revival, particularly in 1917, 1942, and 1990. These attempts were unsuccessful because of different factors. The tomos as a document became a symbol of religious independence only in 2018, so most Ukrainian people did not know of this word before this time. This canonical document officially established the autocephalous (independent) Orthodox Church of Ukraine. On January 5, 2019, the Ecumenical Patriarch of Constantinople Bartholomew and Metropolitan Epiphanius, the newly elected head of OCU, signed it in St. George's Cathedral in Istanbul.

The result of candidates' efforts undoubtedly redirected attention to the main national narratives. As Korostelina showed, Ukrainian society has no single key narrative (Korostelina 2014:169). Instead, it has five narratives which have been present in the minds of Ukrainians during all periods of Ukraine's independence, and compete against each other:

1. The dual (Ukrainian and Russian) identity narrative, wherein the 'Russian side of Ukraine' is imagined as more progressive;

2. The pro-Soviet narrative that describes the 'gold age' of the Soviet era;

3. The fighting-for-Ukraine' narrative based on opposing Ukrainians as victims and Russians as executioners;

4. Recognition of a Ukrainian identity narrative, which contrasts the Ukrainian state with the Russian one, and does not involve a concept of ethnicity. It speaks about a totalitarian Russian and a democratic Ukrainian state.

5. The multicultural civic narrative. This describes Ukraine as a unique multicultural and tolerant society that sees its future in Europe.

Each national narrative includes the so-called 'normative order' - a judgment about the origin of power for the nation and rules concerning this power (Korostelina 2014:31). Thereby, the stories of candidates could fit into some of the 
national narratives, look coherent in relation to their proponents, and convince individuals to vote for the 'proper' candidate. The story told by Zelenskii was appropriate with regard to the conduits of all competing national narratives. In contrast, Poroshenko's story meets the requirements of adherents of the third and fourth Ukrainian national narratives. Therefore, during the period of the deployment of the tomos story, Poroshenko's rating increased from $5.50 \%$ in April 2018 to $17 \%$ in February 2019. He received 15.95\% of votes in the first round of elections in March 2019 and 24.45\% in the second one.

\section{HYPOTHESES}

Both electoral narratives described above were prominent and influential. No doubt the 'Servant of the People' series was made following the typical structure of the TV series. However, we do not know anything about the structure of the tomos narrative. Taking into account its influence, it may be assumed that it also has a well-formed plotline.

H1: The media narrative about the tomos had all the features of well-built classical literature and cinema narratives.

This narrative can be seen on the level of its influence not in its entirety, but through the process of the plot being revealed.

$\mathrm{H} 2$ : Deployment of this narrative led to an increase in voters' involvement in it.

\section{METHOD}

To test the hypotheses, all mentions of the word 'tomos' in a sample of the top 100 Ukrainian news websites were identified (using the common TOP100 sample of the Center for Content Analysis [Zakharchenko 2018]), central Ukrainian TV channels, and newspapers. For this sampling procedure, a commercial monitoring system 'Mediateka' was used. In total, more than 32,000 publications with mentions were found.

Then two trained coders looked through the sample and established the following categories:

- Protagonists (supporters of tomos and Ukrainian church independence)

- Antagonists (critics of tomos)

- Messages used by both sides

- Prominent episodes which influenced the plot. 
The narrative structure was compared with the classical schemata of Hollywood scripts (Orr 2007) - which is composed of exposition, inciting incident, rising action, climax, falling action, resolution, and denouement.

The influence of the narrative was evaluated in two ways. First, plot deployment was compared with the intensity of Google searches for the word tomos. This data was obtained through the Google Trends service, which revealed such data in the form of a percentage, normalized to the maximum value. Second, the average dynamics of Petro Poroshenko's support were calculated. The results of polls provided by top Ukrainian sociological services, and acknowledged by the Sociological Association of Ukraine (Texty.org.ua 2019), were taken into consideration. This typically involved 4-5 electoral polls per month, with questions like: 'If the presidential election took place next Sunday, who would you vote for?' The share of the answer 'Petro Poroshenko' among the respondents who intended to participate in elections and had made their choice at the time of the poll were gathered and averaged throughout each month. As these results varied considerably even among trusted services, the average values of all public polls carried out on certain months and published on the websites of these services were used.

The number of contacts with the audience was evaluated by applying the typical methods of the Center for Content Analysis (Zakharchenko 2018). Namely, the latter was calculated based on public metrics of visits to digital media, circulation numbers for the printed press, the number of TV viewers according to the TV panel for TV, and the average number of listeners (data available through public sources) to the radio.

\section{RESULTS}

\section{Narrative structure}

The media narrative about the tomos had a typical so-called Hollywood structure that most fully involved the audience. This interactive and multiauthorial story was recounted by many people and was shaped by their statements, accounts, reports, and action.

As can be seen in Figure 1, the story started with an exposition in January 2018, four months before the appeal was adopted by the Ukrainian Parliament. Well-known blogger Yurii Hudymenko launched a flash-mob by putting toys under the doors UOC MP (Ukrainian Orthodox Church - Moscow Patriarchate) temples after the refusal of a priest to undertake a burial service for a child 
who had died. He assured us that he was not doing this intentionally with the election in mind. Therefore, this event refreshed the issue of Ukrainian church independence in the media environment and made it more salient.

The inciting incident was sudden enough. It occurred when the president asked Verkhovna Rada (Ukrainian Parliament) to turn to Ecumenical Patriarch Bartholomew I requesting that the independence of the Ukrainian church be granted. All parliamentary groups that positioned themselves as patriotic and pro-European had no choice but to vote for this appeal, otherwise they could have been blamed by Poroshenko for having a pro-Russian position. Then the story developed comparatively slowly because of the summer season. Only one meaningful event happened at that time: a prayer meeting dedicated to the anniversary of the Baptism of Rus, which is celebrated by all Ukrainian Orthodox Churches annually and is seen as the core event that proves the authentic nature of Ukrainian Orthodox Christianity.

Figure 1. Tomos narrative deployment. The number of mentions of the word 'tomos' in the sample and the plot structure

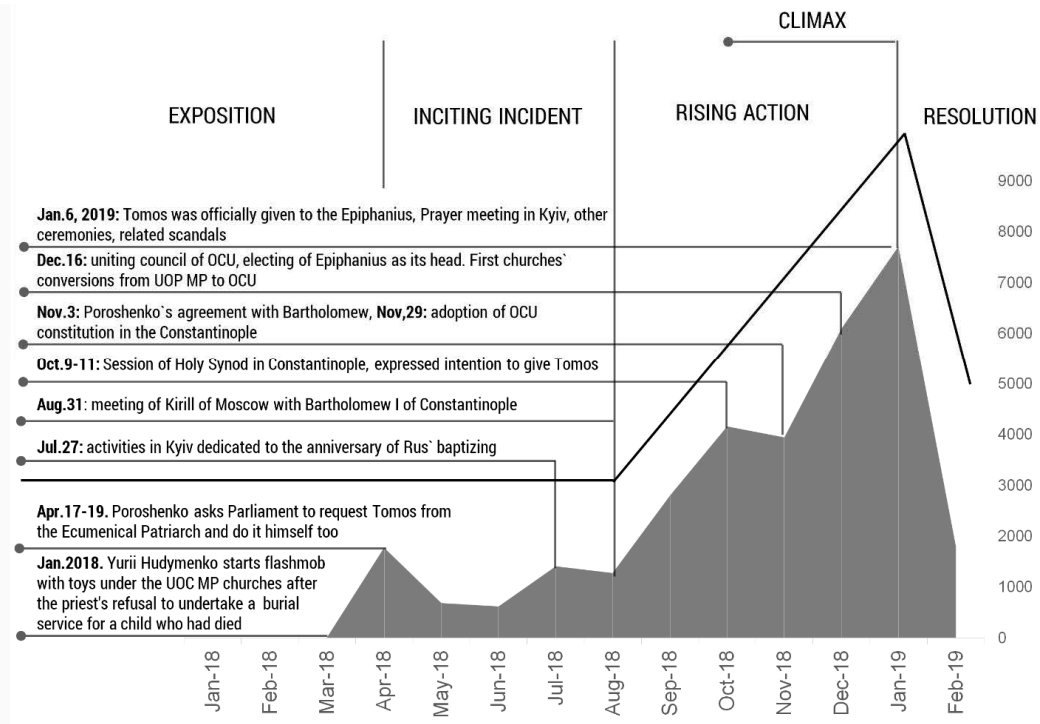

Source: Data from the Mediateka monitoring system, with authors' explanation.

The real start of rising action occurred in September 2018 when a lot of protagonists, as well as antagonists, joined in the narration. After that, the 
structure was typical of the plot of a novel: success was interspersed with failure, and vice versa. Moments of optimism alternated with moments of pessimism for example, at the end of November 2018, just before the constitution of the new Ukrainian church was adopted in Constantinople, two contrasting fake statements in the media were detected and widely shared on Facebook. The first claimed that the tomos had already been received. The second assured the audience that, finally, Bartholomew I of Constantinople had decided to refuse the Ukrainian parliament's appeal. All these messages made the information space more saturated and the plot more exciting.

The climax and resolution were the phases that took place in the period that followed the end of November 2018, when the church constitution was adopted, until January 2019, when the tomos was officially given to the Metropolitan Epiphanius of Kyiv and All Ukraine. After that, attention to the topic steadily decreased and attention overflowed to the election narrative - the so-called 'horse racing' story.

\section{Narrative characters}

All the heroes of the news in this topic may be classified as protagonists or supporters of the tomos, or antagonists/opponents. The first category includes predominantly the top officials and other members of Poroshenko's team (Poroshenko, Head of Parliament Andrii Parubii), as well as the hierarchs of UOC KP (its leader Filaret, and its metropolitans Zorya and Epiphanius) and the Ecumenical Patriarchate of Constantinople (Patriarch Bartholomew). Russian politicians (president Vladimir Putin, his spokesperson Dmitrii Peskov, and Prime-Minister Dmitrii Medvedev), pro-Russian politicians in Ukraine (MPs Vadym Novinskyi and Yurii Boyko), hierarchs of MOC (patriarch Kirill, Bishop Climent), and UPC MP (metropolitan Onufrii) may be located in the second category.

The protagonists significantly predominated in the story compared to the antagonists. Their actions and speeches reached a much larger audience than those of the antagonists. However, the antagonists also were important (see Figure 2). Their participation was quite well embedded in the story logic and framework. They provided the necessary pungency of the plot. A short-term loss of the protagonists' initiative happened in January 2019 in relation to a media incident concerning the presence of a businessman with a mixed reputation (Olexandr Petrovskii) at the ceremony presenting the tomos. 
Figure 2. Key characters and their statements' contact with the audience

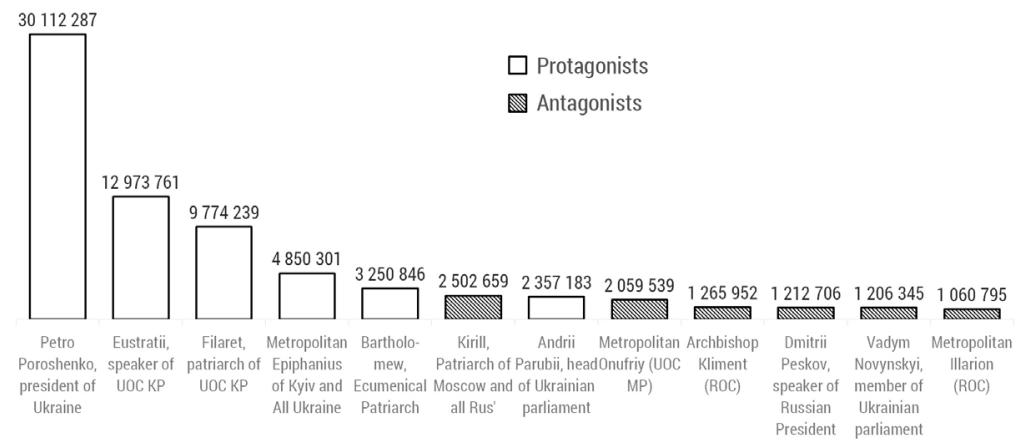

Source: Data generated through the semi-automatic coding of Mediateka media publications dataset, applying the audience reach methodology of the Center for Content Analysis.

\section{Narrative messages}

The story was saturated with detailed PR messages produced by both sides in the conflict. Along with the critics of the idea of church independence, antagonists tried to depreciate the standing of Poroshenko in relation to this achievement (see Table 1).

There is another interesting observation. The roles of protagonists were clearly divided: political issues connected to the story were commented on by politicians, and religious issues by priests. On the other hand, the opposite occurred with the antagonists: Russian and pro-Russian politicians vigorously commented on political as well as on church issues. This may be attributed to the church's level of separation from the state.

\section{Communication channels}

Different media with different political positions - even pro-Russian (Zakharchenko 2018) - provided almost identical stories about the tomos. In each of the analyzed media, the share of texts in which the tomos was mentioned along with antagonists' messages was, on average, $10 \%$, and varied from $8 \%$ to $13 \%$. The other share of about $90 \%$ was comprised of texts with protagonists' messages. This cannot be attributed to the political commitment of the media, thus the main explanation is the criterion of media logic (Harcup-O'Neill, 2001): 
Table 1. Key messages of protagonists and antagonists

\begin{tabular}{|c|c|c|c|c|c|c|}
\hline & Church issues & Political issues & Russian role & $\begin{array}{l}\text { Constantinople's } \\
\text { role }\end{array}$ & $\begin{array}{l}\text { Poroshenko`s } \\
\text { role }\end{array}$ & Future of OCU \\
\hline \multirow{4}{*}{$\begin{array}{c}\text { Prota-gonists' } \\
\text { messages }\end{array}$} & & & & & $\begin{array}{l}\text { Poroshenko } \\
\text { has a historic } \\
\text { role (Parubiy, } \\
\text { Yushchenko) }\end{array}$ & $\begin{array}{l}\text { Lavras will } \\
\text { join the OCU } \\
\text { soon, and } \\
\text { deliberately } \\
\text { (Epiphanius) }\end{array}$ \\
\hline & $\begin{array}{l}\text { The United } \\
\text { Ukrainian } \\
\text { church emerges } \\
\text { (Poroshenko, } \\
\text { Filaret, Zorya) }\end{array}$ & $\begin{array}{l}\text { It is an issue } \\
\text { of national } \\
\text { security (Poro- } \\
\text { shenko) }\end{array}$ & $\begin{array}{l}\text { We will not } \\
\text { ask permission } \\
\text { from Russia } \\
\text { (Poro-shenko) }\end{array}$ & $\begin{array}{c}\text { Bartholomew } \\
\text { will not break ties } \\
\text { with the Russia } \\
\text { church }\end{array}$ & $\begin{array}{c}\text { Bartholomew } \\
\text { got from } \\
\text { Poroshenko } \\
\text { only sweets } \\
\text { instead of a } \\
\text { bribe (his joke) }\end{array}$ & $\begin{array}{l}\text { The tomos is } \\
\text { already written } \\
\text { and will be } \\
\text { presented soon } \\
\text { (Hovorun) }\end{array}$ \\
\hline & $\begin{array}{l}\text { Ukrainian } \\
\text { church deserve } \\
\text { the tomos } \\
\text { (Bartholo- } \\
\text { mew) }\end{array}$ & $\begin{array}{l}\text { The church } \\
\text { must be } \\
\text { separated from } \\
\text { the aggressor } \\
\text { state, above all } \\
\text { (Poro-shenko) }\end{array}$ & $\begin{array}{l}\text { Moscow } \\
\text { is roughly } \\
\text { interfering with } \\
\text { the negotiation } \\
\text { process } \\
\text { (Filaret) }\end{array}$ & $\begin{array}{l}\text { Exarchs will } \\
\text { come to work } \\
\text { on the done } \\
\text { deal of church } \\
\text { independence } \\
\text { (Daniil) }\end{array}$ & $\begin{array}{l}\text { I will not } \\
\text { intervene in } \\
\text { church issues } \\
\text { after the receipt } \\
\text { of the tomos } \\
\text { (Poroshenko) }\end{array}$ & $\begin{array}{c}\text { Church } \\
\text { integration will } \\
\text { be peaceful } \\
\text { (Filaret) }\end{array}$ \\
\hline & $\begin{array}{l}\text { The Russian } \\
\text { church is a } \\
\text { daughter of the } \\
\text { Ukrainian one } \\
\text { (Elpidophorus, } \\
\text { Iow) }\end{array}$ & $\begin{array}{l}\text { Historical } \\
\text { decision } \\
\text { (Parubiy) }\end{array}$ & $\begin{array}{l}\text { Russia is } \\
\text { preparing } \\
\text { provo-cations } \\
\text { (Tymchuk) }\end{array}$ & $\begin{array}{l}\text { It is assumed } \\
\text { that Exarchs } \\
\text { will work as } \\
\text { ambassadors, but } \\
\text { not as administ- } \\
\text { rators (Zorya) }\end{array}$ & $\begin{array}{l}\text { Poroshenko } \\
\text { assures that he } \\
\text { will popularize } \\
\text { the tomos at his } \\
\text { own expense }\end{array}$ & $\begin{array}{l}\text { OCU will not } \\
\text { change the date } \\
\text { of Christmas } \\
\text { date because } \\
\text { this issue } \\
\text { divides people } \\
\text { (Epiphanius) }\end{array}$ \\
\hline \multirow{4}{*}{$\begin{array}{c}\text { Antagonists' } \\
\text { messages }\end{array}$} & $\begin{array}{c}\text { It involves } \\
\text { a split of } \\
\text { the church } \\
\text { (Patriarch } \\
\text { Kirill, Pyeskov, } \\
\text { Boyko, } \\
\text { Medvedchuk, } \\
\text { Illarion) }\end{array}$ & $\begin{array}{l}\text { The church } \\
\text { must be } \\
\text { separated } \\
\text { from the } \\
\text { state (Boyko, } \\
\text { Onufriy) }\end{array}$ & $\begin{array}{l}\text { Russia will } \\
\text { defend the } \\
\text { believers of the } \\
\text { Russian church } \\
\text { (threats of } \\
\text { Pyeskov) }\end{array}$ & $\begin{array}{l}\text { Constantinople } \\
\text { is splitting the } \\
\text { church and wants } \\
\text { to distance the } \\
\text { lavras (Kirill, } \\
\text { Illarion) }\end{array}$ & $\begin{array}{l}\text { The tomos } \\
\text { is a form of } \\
\text { Poroshenko's } \\
\text { publicity, as he } \\
\text { has no other } \\
\text { results }\end{array}$ & $\begin{array}{l}\text { The tomos will } \\
\text { not be given } \\
\text { (Danilevych, } \\
\text { Novinskii, } \\
\text { Antoniy, } \\
\text { Yakubin) }\end{array}$ \\
\hline & $\begin{array}{l}\text { The church in } \\
\text { Ukraine will } \\
\text { be united when } \\
\text { schismatics } \\
\text { repent } \\
\text { (Novinskii) }\end{array}$ & $\begin{array}{l}\text { It is a political } \\
\text { move, not a } \\
\text { religious one } \\
\text { (Novinskii) }\end{array}$ & $\begin{array}{l}\text { Kirill considers } \\
\text { Ukrainian } \\
\text { people to be his } \\
\text { own }\end{array}$ & $\begin{array}{l}\text { Exarchs are } \\
\text { coming to } \\
\text { interfere in } \\
\text { the canonical } \\
\text { territory of the } \\
\text { Russian church } \\
\text { (Onufrii) }\end{array}$ & $\begin{array}{l}\text { Poroshenko } \\
\text { bribed } \\
\text { Bartholomew } \\
\text { (Illarion) }\end{array}$ & $\begin{array}{c}\text { The church } \\
\text { split and } \\
\text { state pressure } \\
\text { may lead to } \\
\text { war (Boyko, } \\
\text { Medved-chuk, } \\
\text { Kirill) }\end{array}$ \\
\hline & $\begin{array}{l}\text { Ukraine is } \\
\text { a canonical } \\
\text { territory of the } \\
\text { Russian church } \\
\text { (Medvedev) }\end{array}$ & $\begin{array}{l}\text { The security } \\
\text { service of } \\
\text { Ukraine is } \\
\text { searching for } \\
\text { priests, and } \\
\text { they need } \\
\text { protection } \\
\text { (Nivinskii) }\end{array}$ & & $\begin{array}{l}\text { The Russian } \\
\text { church is } \\
\text { breaking off ties } \\
\text { with Constanti- } \\
\text { nople (Illarion) }\end{array}$ & $\begin{array}{l}\text { Oligarchs } \\
\text { raised the } \\
\text { money for } \\
\text { the bribe for } \\
\text { Bartholomew, } \\
\text { but Poroshenko } \\
\text { kept it for } \\
\text { himself }\end{array}$ & $\begin{array}{l}\text { I am going to } \\
\text { protect lavras } \\
\text { (Novinskii) }\end{array}$ \\
\hline & $\begin{array}{l}\text { Nothing will } \\
\text { change after } \\
\text { the tomos } \\
\text { (Onufriy) }\end{array}$ & $\begin{array}{l}\text { The tomos } \\
\text { is like the } \\
\text { Crimean } \\
\text { annexation } \\
\text { (Climent) }\end{array}$ & & $\begin{array}{l}\text { Bartholomew } \\
\text { should be } \\
\text { excommunicated } \\
\text { (Climent) }\end{array}$ & $\begin{array}{l}\text { Poroshenko } \\
\text { pays people for } \\
\text { public support } \\
\text { of the tomos }\end{array}$ & $\begin{array}{l}\text { The new } \\
\text { president } \\
\text { of Ukraine } \\
\text { will repeal } \\
\text { the tomos } \\
\text { (Mytrofan) }\end{array}$ \\
\hline
\end{tabular}

Source: Data generated by coding Mediateka media publications dataset. 
i.e. protagonists, especially Ukrainian politicians, are more commonly portrayed in Ukrainian media than the Russian establishment, and have direct connections with them (for example, through the distribution of press releases and giving press conferences in Kyiv). Thereby, the protagonists' messages spread better because of the speakers' importance, as perceived by journalists, the availability of their statements to news editors, the high level of activity of Ukrainian protagonists, topic validity, etc. It should be noted that readers who did not support the church's independence heard the same story about the tomos as their opponents. Thus the only difference could have been in their perceptions. For example, supporters of the tomos could have perceived this story as a kind of archetypical 'Odyssean' narrative about a long journey and ultimate goal, while adversaries saw it as a story about a catastrophe, like the tale about the deaths in Pompeii.

Figure 3. Comparison of media coverage of the tomos with people's engagement (Google search activity and Poroshenko's electoral support)

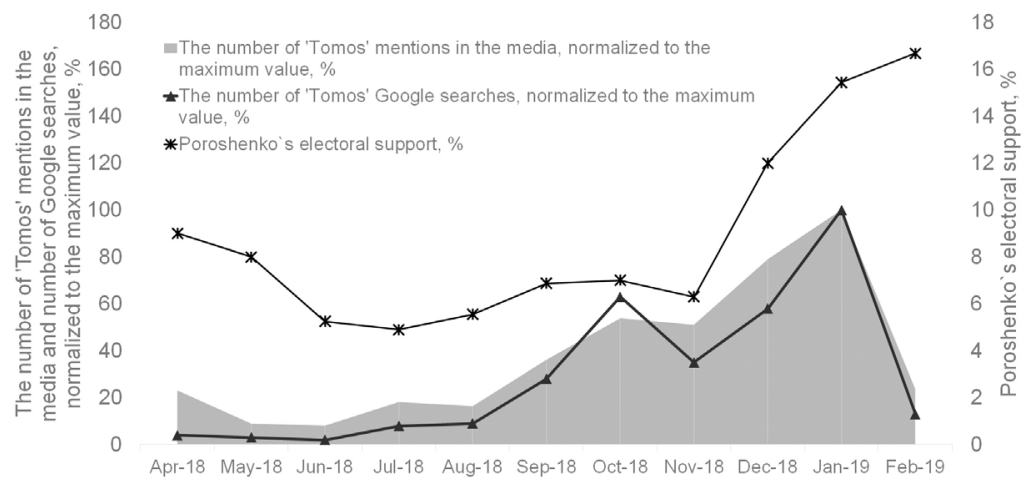

Source: Data from the Mediateka monitoring system, Google trends, and average data from polls released by the 'Rating' group, Kyiv International Institute of Sociology, 'SOCIS' company, Razumkov Centre, GFK Ukraine, Ukrainian Institute of Social Investigations (named after Oleksandr Yaremenko) and the Center for Social Monitoring.

\section{Readers' involvement}

A comparison of the number of mentions of the tomos in media using Google Trends data and polls data (see Figure 3) indicates the good correlation between these three parameters between April 2018 and January 2019 (see Table 2). After this point, diverging trends occur, as followers of the story switched to 
the 'horse racing' electoral narrative. On the other hand, almost throughout the entire period, Google search interest in 'tomos' was less than the media coverage of this topic. Only once was the situation the opposite - in October, when the uniting council of OCU was held - and in January 2019, both indicators reached their maximum. In other words, almost all the time media were more interested in the topic of the tomos than their readers.

Table 2. Correlations coefficients of the number of mentions of 'tomos' in media, Google Trends data, and polling data between April 2018 and January 2019

\begin{tabular}{cccc}
\hline & Media mentions & Google search activity & Electoral support \\
\hline Media mentions & 1.00 & & \\
\hline Google search activity & 0.96 & 1.00 & 1.00 \\
\hline Electoral support & 0.82 & 0.76 & \\
\hline Source: Author's own calculations. & & &
\end{tabular}

\section{DISCUSSION AND CONCLUSION}

Based on the narrative structure described in the previous chapter, it is clear that hypothesis 1 is true: the structure of the tomos narrative portrayed by Ukrainian media shows that it was similar to that of classic Hollywood plots. It is unlike most other media narratives that are present in the information space.

Therefore, it makes sense that public attention to the narrative and its impact on the electoral decision are clearly supported by the correlation. This proves hyposethis 2. Even people who were not interested in Orthodox Christianity started to root for the result of this story. The proof can be seen in a well-known Facebook meme: 'I am an atheist. But an atheist of Kyiv Patriarchate' (Novoe Vremya 2018).

As can be seen from Figure 3, the main driver of this public attention was media attention - which, for its part, was constituted by the media logic (Harcup-O'Neill 2001). It may be assumed that the main impact drivers were the media-related weight of the Ukrainian president, the validity of this issue for a big part of Ukrainian society, its singular importance for the Ukrainian political process, and strong resistance from Russia and pro-Russian politicians in Ukraine.

Almost all resistance was inefficient while it remained related to the topic of the Orthodox Church. All the messages of antagonists remained an expected part of the plot. Therefore, supporters of church independence had no reason to change their opinion about the issue. Only at the end of the story did pro-Russian 
media manage to make corruption the framing element of the topic (How the "Narik" ... 2019). This was the first time that supporters were influenced by opponents' messages.

Despite the absence of limitations to an Orthodox audience, this narrative was limited to the patriotic part of the electorate. We may assume that people who were neither Orthodox Christians nor pronounced patriots were not involved in this narrative, and were not convinced by it. As a result, Poroshenko's support did not exceed the $24.45 \%$ obtained in the second round of elections.

Nevertheless, the story about the tomos became so influential that it started being used as one of the defining factors of the dichotomy between patriots and non-patriots (Maidanuk 2019); between a spiritual Russian church, and a downto-earth European church (Vasiliy Shchipkov: Presenting ... 2019) - and even as one of the goals in the strategic confrontation with Russia (NISR 2019).

Therefore, the latter can be considered not only a media narrative, but also part of the national narrative (pro-Ukrainian as well as pro-Russian), and even as an element of the strategic narrative. Furthermore, it may be assumed that it was purposefully made part of these larger narratives.

\section{REFERENCES}

Burnes, S. (2011) Metaphors in press reports of elections: Obama walked on water, but Musharraf was beaten by a knockout. Journal of Pragmatics, Vol. 43, No. 8., pp. 2160-2175, https://doi.org/10.1016/j.pragma.2011.01.010

Busselle, R. - H. Bilandzic (2008) Fictionality and perceived realism in experiencing stories: A model of narrative comprehension and engagement. Communication Theory, Vol. 18, No. 2., pp. 255-280, https://doi.org/10.1111/ j.1468-2885.2008.00322.x

Capone, A. (2010) Barack Obama's South Carolina speech. Journal of Pragmatics, Vol. 42, No. 11., pp. 2964-2977, https://doi.org/10.1016/j.pragma.2010.06.011

Gerbaudo, P. (2016) Rousing the Facebook crowd: Digital enthusiasm and emotional contagion in the 2011 protests in Egypt and Spain. International Journal of Communication, Vol. 10., pp. 254-273

Harcup, T. - D. O'Neill (2001) What is news? Galtung and Ruge revisited. Journalism Studies, Vol. 2, No. 2., pp. 261-280, https://doi. org/10.1080/14616700120042114

Herman, D. (2004) Toward a transmedial narratology. In: Ryan, M.-L. (ed.): Narrative Across Media: The Languages of Storytelling. pp. 43-75, Lincoln, University of Nebraska Press 
Hoenig, L. J. (2020) Theodore Roosevelt's tattoos and the presidential election of 1912. Clinics in Dermatology, Vol. 38, No. 5., pp. 563-567, https://doi. org/10.1016/j.clindermatol.2020.08.001

How the "Narik" topic was boosted on January 5th (2019) Facebook of Center for the Content Analysis. https://www.facebook.com/ukrcontent/ photos/a.1028140107204280/2278971735454438/?type=1\&theater

JDN (2013) Joint Doctrine Note 2-13. Commander's Communication Synchronization. December 16, 2013; https://www.jcs.mil/Portals/36/ Documents/Doctrine/jdn_jg/jdn2_13.pdf

Korostelina, K. V. (2014) Constructing the Narratives of Identity and Power: Self-Imagination in a Young Ukrainian Nation. Lanham, Lexington Books Lyotard, J.-F. - G. Bennington - B. Massumi (1984) The postmodern condition: A report on knowledge. Poetics Today, Vol. 5, Issue 4., University of Minnesota Press; https://doi.org/10.2307/1772278

Maidanuk, V. (2019) The dark side of the Tomos. ZAXID.NET. https://zaxid. net/temniy bik tomosu_n1473672

McCombs, M. B. E. - D. L. Shaw (1972) The agenda-setting function of mass media. The Public Opinion Quarterly, Vol. 36, Issue 2., Oxford University Press; https://doi.org/10.2307/2747787

Mihailidis, P.- S. Viotty (2017) Spreadable spectacle in digital culture: Civic expression, fake news, and the role of media literacies in "post-fact" society. American Behavioral Scientist, Vol. 61, No. 4., pp. 441-454, https://doi. org/10.1177/0002764217701217

Musolff, A. (2005) Metaphor scenarios in public discourse. Metaphor and Symbol, Vol. 21, No. 1., pp. 23-38, https://doi.org/10.1207/s15327868ms2101_2 NISR - The National Institute of Strategic Research (2019) Tomos about the autocephaly of Ukrainian Orthodox Church: Meanings and challenges. https:// niss.gov.ua/doslidzhennya/analitichni-materiali/gumanitarniy-rozvitok/ tomos-pro-avtokefaliyu-ukrainskogo

Nedelcheva, I. (2016) Analysis of transmedia storytelling in pokémon go. Open science index, Journal of Humanities and Social Sciences, Vol. 10, No. 11., pp. 3744-3752

Novoe Vremya (2018) Atheist of the Ukrainian Patriarchate. Web jokes about Tomos. Novoe Vremya, October 12, 2018; https://nv.ua/ukr/lifestyle/atejistukrajinskoho-patriarkhatu-u-merezhi-zhartujut-pro-tomos-2499977.html

Ochs, E. - L. Capps (2001) Living narrative: Creating lives in everyday storytelling. Language in Society, Vol. 34, Issue 3, Harvard University Press

Orr, S. (2007) Teaching play analysis: How a key dramaturgical skill can foster critical approaches. Theatre Topics, Vol. 13, No. 1., pp. 153-158, https://doi.org/10.1353/tt.2003.0015 
Pihlaja, S. (2017) 'When Noah built the ark...' Metaphor and biblical stories in Facebook preaching. Metaphor and the Social World, Vol. 5, No. 1., pp. 86-101, https://doi.org/10.1075/msw.7.1.06pih

Pocheptsov, G. (2012) Cognitive approaches to the information space analysis. Media Sapiens, https://ms.detector.media/ethics/manipulation/kognitivni pidkhodi_do_analizu_informatsiynogo_prostoru/

Schneiker, A. (2019) Telling the story of the superhero and the anti-politician as president: Donald Trump's branding on Twitter. Political Studies Review, Vol. 17, No. 3., pp. 210-223, https://doi.org/10.1177/1478929918807712

Seeger, M.W. - T. L. Sellnow (2016) Narratives of Crisis: Telling Stories of Ruin and Renewal. Stanford, CA: Stanford University Press

Sides, J. (2006) The origins of campaign agendas. British Journal of Political Science, Vol. 36, No. 3., pp. 407-436, https://doi.org/10.1017/ S0007123406000226

Texty.org.ua (2019) Rating sellers. The false sociologists list. Texty.Org.Ua. http://texty.org.ua/d/socio/\#good

Vasiliy Shchipkov: Presenting Tomos to OCU is like a terrorist attack (2019) Russian Peoples' Line. http://ruskline.ru/politnews/2019/yanvar/11/vasilij_ wipkov_darovanie_tomosa_pcu_pohozhe_na_terakt/

Zakharchenko, А. (2017) Феномен сюжетних ліній в інформаційному просторі українських медіа та соціальних мереж. In: Shevchenko, V. E. (ed.): Crossmedia: Content, Technologies, Perspectives. pp. 92-101. Taras Shevchenko National University of Kyiv.

Zakharchenko, A. (2018) How do we explore you: Methodology and samples of the Content Analysis Center. Kyiv: The Center for Content Analysis. http:// ukrcontent.com/blog/yak-mi-vas-doslidzhuemo-metodiki-i-vibirki-centrukontent-analizu.html

Zakharchenko, A. (2019) "Russian style propaganda" and "retired opinion leaders": How Zelenskyi and Poroshenko fought in social networks. Ukraiinska Pravda, May 3, 2019, https://www.pravda.com.ua/columns/2019/05/3/7214176/ Zakharchenko, A. - Y. Maksimtsova - V. Iurchenko - V. Shevchenko S. Fedushko (2019) Under the conditions of non-agenda ownership: Social media users in the 2019 Ukrainian presidential elections campaign. CEUR Workshop Proceedings. Vol. 2392: COAPSN-2019 International Workshop on Control, Optimisation and Analytical Processing of Social Networks, pp. 199-219, http://ceur-ws.org/Vol-2392/paper15.pdf 